\title{
The Relationship of Leg Muscle Strength on Dynamic Balance among Elderly
}

\author{
Kadek Liza Widya Astari, ${ }^{1 *}$ I Putu Prisa Jaya, ${ }^{1}$ I.A Pascha Paramurthi ${ }^{1}$
}

\begin{abstract}
Background: Elderly is someone who has reached the age of 60 years and over. Along with increasing age, a person will experience physical changes in the musculoskeletal system, which causes a decrease in the number of muscle fibers and muscle mass. This can result in a decrease in muscle strength, especially in the leg muscles, which is one of the factors that can affect the balance of the human body. The decreased dynamic balance will result in the risk of injury in the elderly.

Objective: The aim of this study was to prove the relationship of leg muscle strength and dynamic balance in the elderly.

Methods: The design of this study was a cross sectional study conducted in April 2021 with a population of all elderly people in Banjar Jasan, Desa Sebatu, Kecamatan Tegalalang, Kabupaten

samples were obtained. Measurement of muscle strength using a Leg Dynamometer and dynamic balance using the TUG test. Data analyzed using computer software, namely the Pearson test to determine the relationship of leg muscle strength and dynamic balance.

Results: The results showed that from 46 elderly there was a relationship of leg muscle strength and dynamic balance using the Pearson test with $p$ results of $0.001(p<0.05)$ with a correlation coefficient of $-0.819(r>0.05)$ which indicates a very strong correlation.

Conclusion: It can be concluded that there is a very strong and negative relationship between leg muscle strength and dynamic balance in the elderly.
\end{abstract} Gianyar, that met the inclusion and exclusion criteria, so that 46
'Study Program of Physical Therapy, College of Health Sciences, Universitas Bali Internasional

*Corresponding to: Kadek Liza Widya Astari, Study Program of Physical Therapy, College of Health Sciences, Universitas Bali Internasional; Email: lizawidya2006@gmail.com

Received : 2021-07-26 Accepted : 2021-11-01 Published : 2021-12-02

Keywords: elderly, dynamic balance, leg muscle strength

Cite this Article: Astari, K.L.W., Jaya, I.P.P., Paramurthi, I.A.P. 2021. The Relationship of Leg Muscle Strength on Dynamic Balance among Elderly. Physical Therapy Journal of Indonesia 2(2): 67-72. D0I: 10.51559/ptji.v2i2.27

\section{INTRODUCTION}

Elderly is the final stage of the human life cycle, and is susceptible to diseases related to the aging process, which is characterized by a decrease in the ability and function of human body tissues. This can happen because of the degeneration process that is greater than the regeneration process. ${ }^{1}$

Along with increasing age, a person will experience physical changes, which is related to a decrease in the ability or capacity of body tissues, especially in the physiological functions of the musculoskeletal system and the neurological system. ${ }^{2}$ The main components in the musculoskeletal system are bones and connective tissue that function as constituents of the body, which is approximately $25 \%$ of body weight and $50 \%$ consists of muscle. ${ }^{3}$ Physiological changes in the musculoskeletal system that occur during the aging process are reduced muscle mass, myofibril degeneration, tendon contraction (shrinkage), and muscle fiber atrophy. These changes can have an impact on decreasing muscle strength, especially leg muscles which are one of the important components in controlling body balance. ${ }^{4}$

Leg muscle strength is the ability of muscles to withstand loads during work, this ability is produced by muscle contractions in the legs, which occur to perform a supportive movement. Therefore, the leg muscles will produce movement in carrying out daily activities. ${ }^{5}$ Decreased leg muscle strength can cause dynamic balance disorders, resulting in slow movements, short strides, inability of the feet to step and delay in anticipating dangerous situations such as slips, trips, or falls. ${ }^{6}$

Dynamic balance is the ability to maintain the body's position in motion and where the center of gravity (COG) is always changing, while static balance is the ability to maintain the body's position in a state of rest and where the center of gravity (COG) does not change. ${ }^{7}$

Based on research conducted by Zarei et al., (2020) showed that the muscle strength of hip extension, hip abduction, hamstring, quadriceps, and ankle plantar flexion had a significant relationship with dynamic balance and the risk of falling. In other words, increasing muscle strength 
will reducing dynamic balance and the risk of falling in the elderly. ${ }^{8}$

Another study conducted by Asti et al (2017) found that respondents with good moderate muscle strength had a low risk of falling, and no elderly with moderate muscle strength had a high risk of falling. In other words, this study shows a relationship between muscle strength and the risk of falling in the elderly caused by balance disorders. ${ }^{9}$ Another study conducted by Noviyanti (2014) showed an opposite relationship between variables, where the greater the strength of the quadriceps femoris muscle, the lower the risk of falling in the elderly. This shows that there is a relationship between quadriceps femoris muscle strength and the risk of falling in the elderly. ${ }^{10}$

Based on the problems, the presentation of the results of preliminary studies and the lack of research on the relationship between leg muscle strength and dynamic balance in the elderly in Indonesia, this study was conducted to determine the correlation between leg muscle strength and dynamic balance in the elderly.

\section{METHODS}

This research is an analytic observational study with a descriptive correlational design and using a cross sectional research design. The research was conducted in Banjar Jasan, Desa Sebatu, Kecamatan Tegallalang, Kabupaten Gianyar in April 2021.

The population in this study was an affordable population, namely the elderly living in Banjar Jasan, Desa Sebatu, Kecamatan Tegalalang, Kabupaten Gianyar who met the inclusion and exclusion criteria. The sampling with the inclusion criteria: (a) Elderly women and men aged 60-74 years, (b) the ability to walk as far as 12 meters without assistance, (c) the ability to follow and respond to instructions without assistance, (d) good general condition with normal vital signs, and (e) agreed to informed consent. Exclusion criteria: (a) Elderly taking drugs that affect balance, (b) elderly with a history of injury or fracture in the upper and lower extremities within the last 6 months, (c) having muscle problems and neurological diseases, and (d) there are no open wounds.

\section{Research Procedure}

This study had obtained ethical clearance from the Research Ethics Commission of the University of Bali International No.02.0126/UNBI/EC/III/2021. The study's goal, protocol, and outcomes were explained to the participants, and they volunteered to participate by signing a consent form.

Data was collected by door to door and interviewed to find respondents who met the selection criteria. After the respondent met the selection criteria and was willing to become the research sample, vital signs were checked and measurements were taken of leg muscle strength and dynamic balance. Leg muscle strength was measured using the Leg Dynamometer, while dynamic balance was measured using the Time Up and Go Test (TUGT).

\section{Research Instrument}

The instrument used to measure leg muscle strength in the elderly is the Takei Leg Dynamometer, with an accuracy of $0.5 \mathrm{~kg}$. Leg Dynamometer is a tool used to measure the components of leg muscles strength (i.e. quadriceps, hamstrings, and gluteus maximus). Leg Dynamometer has a validity value of 0.86 and a reliability of $0.91 .^{11}$

The interpretation of the measurement results is with male criteria: 259.5 excellent, $187.5-259$ good, 127.5-187 average, $84.5-127$ below average and 84 poor. In women 219.5 excellent, 171.5-219 good, 127.5-171 average, 81.5-127 below average and 81 poor. ${ }^{12}$ As a correction for the ageing process, the numbers acquired from the leg dynamometer are increased by $10 \%$ in the elderly. ${ }^{13}$

The Time Up and Go Test (TUGT) is a simple test that aims to assess functional status such as mobility, balance, walking ability, and the risk of falls in the elderly. ${ }^{14}$ The time measurement instrument uses a Seiko brand stopwatch with an accuracy of 0.01 seconds. As well as the distance measurement instrument using a Wipro brand meter with a length of 5 meters.

The TUG validity test in the research conducted by Utomo and Takarini (2009), showed that the TUG is a valid balance measurement tool..$^{15}$ The validity of TUG shows a strong correlation between TUG and Dynamic Gait Index (DGI) $(r=-0.754$, $\mathrm{p}<0.05)$. The test-retest reliability value on TUG showed very good results, namely 0.92 , inter-rater reliability $0.91-99$ and intra-rater reliability $0.92 .^{16}$ Time Up and Go test results, which are normal: $<10$ seconds, low : $10-<20$ seconds, moderate risk: 2029 seconds, high: $>30$ seconds. ${ }^{14}$

\section{Statistical data analysis}

The research data were analyzed using the SPSS v.16.0 for windows program with the following steps:

1. Descriptive Analysis

Characteristics of respondents: data on the characteristics of the research sample include, gender, age, leg muscle strength, and dynamic balance, which are shown in a descriptive table. 
2. Hypothesis Analysis

The linearity test is carried out through a test of linearity, to find out that between the independent and dependent variables there is a linear relationship. The Shapiro-Wilk test was used to measure the normal distribution of data. All the data were normally distributed and linear. Pearson's correlation coefficient was used to examine the relationship between leg muscle strength and dynamic balance.

\section{RESULTS}

\section{Characteristics of Respondents}

Respondents in this study were the elderly in Banjar Jasan, Desa Sebatu, Kecamatan Tegallalang, Kabupaten Gianyar with the sampling technique using total sampling. The total population consisted of 90 elderly, there were 44 respondents who did not meet the inclusion and exclusion criteria, so that the elderly who participated in this study amounted to 46 elderly. The respondent flow diagram is presented in Figure 1.

The respondents of this study consisted of 18 males (39.1\%) and 28 females (60.9\%). Most

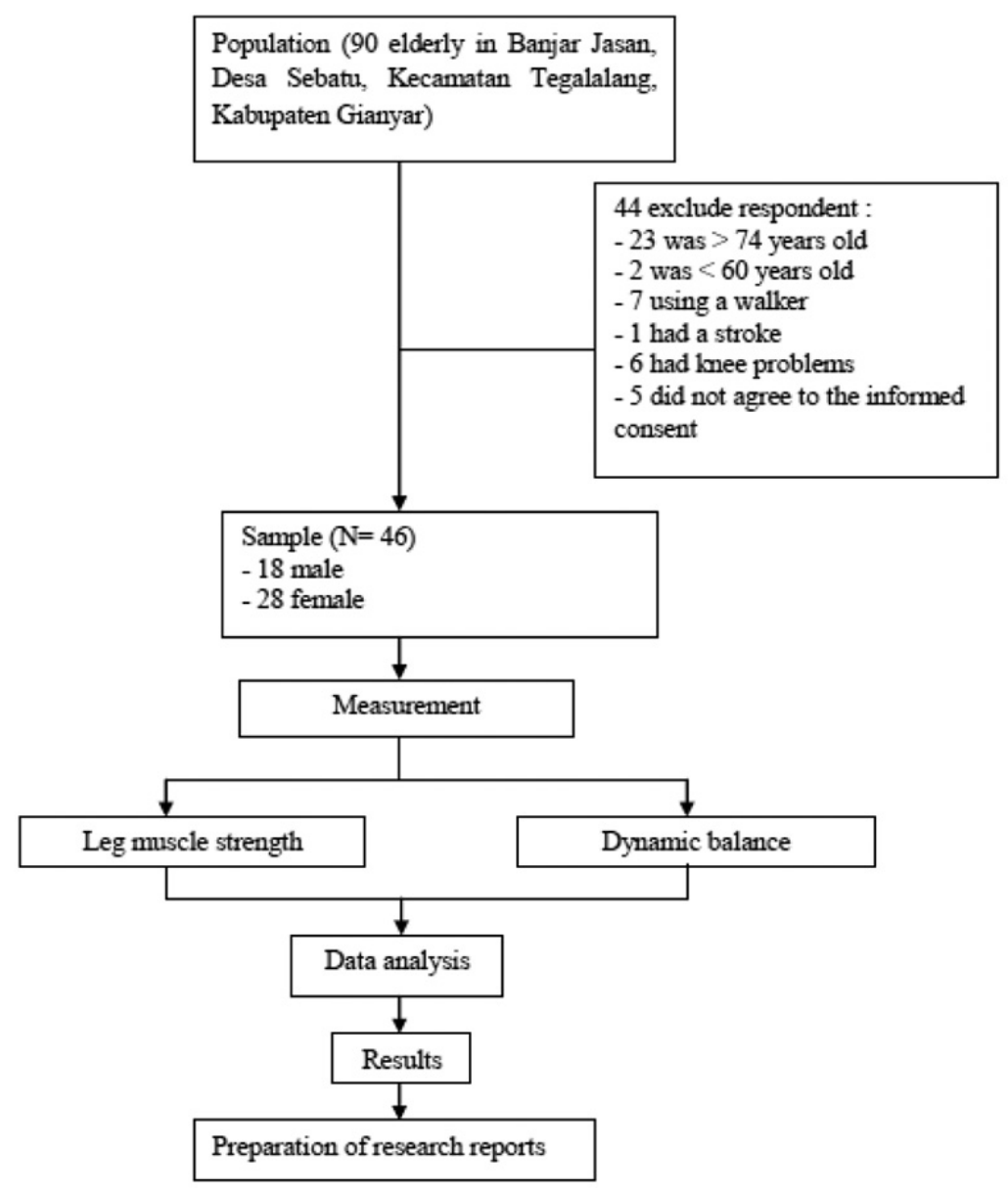

Figure 1. Research flow chart respondents are aged 60-64 years as many as 17 respondents (37.0\%). Table 1 shows that the leg muscle strength of all respondents, 18 males (100\%) and 28 females $(100 \%)$ was in the poor category. The distribution of respondents based on dynamic balance shows that the majority of respondents are in dynamic balance with a moderate fall risk category, namely 31 respondents (67.4\%).

\section{The Relationship of Leg Muscle Strength to Dynamic Balance}

To prove that there is a negative relationship between leg muscle strength and dynamic balance in the elderly, the Pearson test was carried out. The results of the linearity test have a linear pattern with a p value $=0.001(p<0.05)$ and the value of linearity deviation with a value of 0.106 . For the normality test using Shapiro-Wilk in the variable leg muscle strength $(p=0.302)$ and dynamic balance $(p=$ 0.125 ) the $p$ value $>0.05$, which means the data is normally distributed.

To determine whether there is a negative relationship between leg muscle strength and dynamic balance in the elderly, the Pearson statistical test was carried out. The cross table and Pearson test results can be seen in the Table 2. Respondents with poor leg muscle strength category on dynamic balance who are included in the low fall risk category are 13 respondents $(28.3 \%)$, the category of poor leg muscle strength on dynamic balance which is included in the category of moderate fall risk as many as 31 respondents $(67.4 \%)$, and the category of poor leg muscle strength in dynamic balance which is included in the category of high fall risk as many as 2 respondents (4.3\%).

The output results show the value of $\mathrm{p}=0.0001$ $(\mathrm{p}<0.05)$, so it can be said that there is a relationship between leg muscle strength and dynamic balance in the elderly. The correlation value (r) Pearson is -0.819 which states that the level of the relationship between leg muscle strength and dynamic balance includes a strong correlation with a negative direction.

\section{DISCUSSION}

\section{Characteristics of Respondents}

Characteristics of respondents based on age showed that the majority of respondents were aged 60-64 years, as many as 17 respondents. From the results of the study, it can be seen that all elderly have poor leg muscle strength. Increasing a person's age in adulthood will be followed by a decrease in body tissue, so that it can reduce the ability of muscles and other organ functions. ${ }^{17}$

The results of this study can be seen that the 
elderly tend to have a dynamic balance with a moderate fall risk category which states that the older the respondent, the higher the risk of falling. During the COVID-19 pandemic, elderly gymnastics in Banjar Jasan, Desa Sebatu, Kecamatan Tegalalang, Kabupaten Gianyar was canceled, causing the elderly to be less productive in carrying out daily activities outside the home. A decrease in balance in a person does not only occur due to a decrease in muscle strength or illness, but daily activities, because daily activities are one of the factors and have benefits in the balance of the human body. In a study conducted by Deniro et al (2017), which stated that with age a person will experience a process of degeneration and a decrease in the ability of daily activities, resulting

Table 1. Characteristics of Respondents

\begin{tabular}{|c|c|c|}
\hline Characteristics & Frequency (f) & Percentage (\%) \\
\hline \multicolumn{3}{|l|}{ Gender } \\
\hline Male & 18 & 39.1 \\
\hline Female & 28 & 60.9 \\
\hline \multicolumn{3}{|l|}{ Ages } \\
\hline $60-64$ & 17 & 37.0 \\
\hline $65-69$ & 13 & 28.3 \\
\hline $70-74$ & 16 & 34.8 \\
\hline \multicolumn{3}{|l|}{ Male Leg Muscle Strength } \\
\hline Excellent & 0 & 0 \\
\hline Good & 0 & 0 \\
\hline Average & 0 & 0 \\
\hline Below Average & 0 & 0 \\
\hline Poor & 18 & 100 \\
\hline \multicolumn{3}{|l|}{ Female Leg Muscle Strength } \\
\hline Excellent & 0 & 0 \\
\hline Good & 0 & 0 \\
\hline Average & 0 & 0 \\
\hline Below Average & 0 & 0 \\
\hline Poor & 28 & 100 \\
\hline \multicolumn{3}{|l|}{ Dynamic Balance } \\
\hline Normal & 0 & 0 \\
\hline Low & 13 & 28.3 \\
\hline Moderate & 31 & 67.4 \\
\hline High & 2 & 4.3 \\
\hline Total & 46 & 100 \\
\hline
\end{tabular}

Table 2. Cross-Table of Leg Muscle Strength with Dynamic Balance

\begin{tabular}{|c|c|c|c|c|c|c|c|c|c|c|}
\hline \multirow{3}{*}{$\begin{array}{l}\text { Leg Muscle } \\
\text { Strength }\end{array}$} & \multicolumn{6}{|c|}{ Dynamic Balance } & \multirow{2}{*}{\multicolumn{2}{|c|}{ Total }} & \multirow{3}{*}{$\mathbf{p}$} & \multirow{3}{*}{$r$} \\
\hline & \multicolumn{2}{|c|}{ Low } & \multicolumn{2}{|c|}{ Moderate } & \multicolumn{2}{|c|}{ High } & & & & \\
\hline & $f$ & $\%$ & $f$ & $\%$ & $f$ & $\%$ & $\mathbf{N}$ & $\%$ & & \\
\hline Excellent & 0 & 0 & 0 & 0 & 0 & 0 & 0 & 0 & & \\
\hline Good & 0 & 0 & 0 & 0 & 0 & 0 & 0 & 0 & & \\
\hline Average & 0 & 0 & 0 & 0 & 0 & 0 & 0 & 0 & 0.001 & -0.819 \\
\hline Below Average & 0 & 0 & 0 & 0 & 0 & 0 & 0 & 0 & & \\
\hline Poor & 13 & 28.3 & 31 & 67.4 & 2 & 4.3 & 46 & 100 & & \\
\hline
\end{tabular}

in a decrease in muscle flexibility, muscle strength, muscle elasticity, and speed in terms of anything that causes a greater risk of falling. ${ }^{18}$

In this study, male respondents had greater average muscle strength than women. In general, men have stronger muscle strength than women. Male muscle strength when young is almost the same as young girls, after puberty boys will experience a significant increase in muscle strength than girls. The biggest difference appears in the middle age phase, which is between the ages of 30 to 50 years. The increase in muscle strength is related to the increase in muscle mass after puberty, because after puberty the muscle mass of male increases by $50 \%$ compared to female mass. ${ }^{19}$ Hormones can also affect a person's muscle strength. Men are physically stronger than women due to differences in growth hormones. In adolescence, growth hormone and testosterone still have an important role in the growth of muscle mass. At the age of over 40 years, the hormone testosterone will decrease rapidly, namely by 20 to $50 \%$ of its peak value at the age of 80 years. ${ }^{20}$

In this study, it was also found that female respondents had a higher risk of falling than male respondents. In general, elderly women are more at risk of falling or experiencing balance disorders than elderly men, because a lack of the hormone estrogen in elderly women can cause a decrease in osteoclastogenesis and loss of bone mass. ${ }^{21}$ Loss of bone mass can cause changes in posture in the elderly, so that it can affect dynamic balance disorders or the risk of falling. This study is in accordance with previous research conducted by Sihombing and Athuhema (2021), elderly women with a low risk of falling are only $5.6 \%$ and elderly men $27.7 \%$, which shows that the percentage of low fall risk in elderly women is smaller than elderly men, this is due to changes in posture that cause elderly women to be more at risk of experiencing balance disorders. ${ }^{22}$ Changes in bending posture will change the center of gravity (COG). So that it can cause muscle weakness or fatigue corestability decreases the dynamic stability of the trunk, thereby causing loss of balance control. ${ }^{23}$ Decreased dynamic balance will result in the risk of injury. This is due to low muscle mass which results in decreased muscle strength, resulting in loss of balance in a person's body in a fixed position or moving or walking. ${ }^{24}$

\section{The Relationship between Leg Muscle Strength and Dynamic Balance}

The results of the data analysis test showed that there was a significant relationship between leg muscle strength and dynamic balance with $\mathrm{p}$ value $=0.001$. 
Pearson correlation or $\mathrm{r}$ value of -0.819 was also obtained which indicates leg muscle strength with dynamic balance is negatively correlated, which means that the higher the leg muscle strength, the lower the risk of falling, and vice versa.

There was also a significant relationship between ankle dorsiflexion muscle strength with dynamic balance and risk of falling $(\mathrm{p} \leq 0.05) .{ }^{8}$ This is because balance is a complex movement skill that describes postural dynamics in preventing falls. ${ }^{25}$ Postural control and balance is a function of the interaction between the nervous and musculoskeletal systems. Postural control is achieved through the close and complex interaction between sensory input and appropriate movement responses, including efficient control of the movement system and muscle strength. ${ }^{26}$

The occurrence of muscle weakness in the elderly will have an impact on balance so that it can increase the risk of falling which causes dependence in carrying out daily activities. ${ }^{27}$ In the musculoskeletal system, muscle strength is an important factor that affects physical activity. Muscle strength can also be reduced due to lack of movement or daily physical activity cause to muscle atrophy. ${ }^{28}$ This research is also in line with Utami's research (2017) in Desa Jaten, Kecamatan Juwiring Klaten which states that a decrease in muscle strength is a real change experienced in the aging process which can be caused by various factors, one of which is a decrease in muscle mass. Decreased muscle strength will result in the magnitude of the incidence of falls in the elderly. ${ }^{29}$

\section{CONCLUSION}

Based on the results of this study, the leg muscle strength obtained by all the elderly in Banjar Jasan, Desa Sebatu, Kecamatan Tegalalang, Kabupaten Gianyar, both male and female, is included in the category of poor muscle strength. Moderate fall risk is the most common dynamic balance frequency in the elderly in Banjar Jasan, Desa Sebatu, Kecamatan Tegalalang, Kabupaten Gianyar. There is a relationship between leg muscle strength and dynamic balance in the elderly in Banjar Jasan, Desa Sebatu, Kecamatan Tegalalang, Kabupaten Gianyar with a value of $p=0.001(p<0.05)$

\section{CONFLICT OF INTEREST}

No any benefit was received by the authors or authors' affiliations from any commercial party.

\section{FUNDING}

None.

\section{ACKNOWLEDGEMENT}

The authors would like to thank the heads of Desa Sebatu, Kecamatan Tegalalang, Kabupaten Gianyar, for giving permission and information during this study period. And thanks to the supervisor for the guidance and support during this study. This study received no funding from any institution.

\section{AUTHORS CONTRIBUTIONS}

KLWA conceived the study design, data collection, and writing the manuscript; IPPJ and IAPP conducted data analysis and writing the manuscript.

\section{REFERENCES}

1. Widarti R, Triyono E. Pemberian Ankle Strategy Exercise Pada Lansia Terhadap Keseimbangan Dinamis. Gaster. 2018;16(1):83-93.

2. Padila P, Kep N. Asuhan Keperawatan Penyakit Dalam. Yogyakarta: Nuha Medika. 2013.

3. Prawibowo S, Purwaningrum R, Rahmattullah R. Fisiologi dan Pengukuran Kerja (FPK) Materi Musculoskeletal: Universitas Islam Indonesia, Yogyakarta; 2019.

4. Manangkot MV, Sukawana IW, Witarsa IMS. Pengaruh senam lansia terhadap keseimbangan tubuh pada lansia di lingkungan Dajan Bingin Sading. J Keperawatan Community of Publishing Nursing. 2016;4(1):24-7.

5. Andita D. Hubungan kekuatan otot tungkai dan otot perut terhadap akurasi shooting pada ekstrakurikuler futsal SMA Muhammadiah 2 Yogyakarta. Jurnal Pendidikan Jasmani Indonesia. 2015;3(2):10-21.

6. Septina S. Perbedaan Tingkat Keseimbangan Tubuh Antara Lansia Yang Mengikuti Senam Dengan Lansia Yang Tidak Mengikuti Senam Di Yayasan Gerontologi Kecamatan Wajak Kabupaten Malang. Jurnal Wiyata. 2015;2(1):67-72.

7. Supriyono E. Aktifitas Fisik Keseimbangan Guna Mengurangiresiko Jatuh pada Lansia. Jorpres (Jurnal Olahraga Prestasi). 2015;11(2).

8. Zarei H, Norasteh AA, Koohboomi M. The Relationship Between Muscle Strength and Range of Motion in Lower Extremity With Balance and Risk of Falling in Elderl. Physical Treatments-Specific Physical Therapy Journal. 2020;10(1):33-40.

9. Asti NPIP, Yanti NLPE, Astuti IW. Hubungan Kekuatan Otot dan Tingkat Stres dengan Risiko Jatuh pada Lansia. Jurnal Ners Widya Husada. 2020;4(2):41-6.

10. Noviyanti S, Santoso TB, Fis S, Widodo A, Fis S. Hubungan Kekuatan Otot Quadriceps Femoris dengan Risiko Jatuh pada Lansia: Universitas Muhammadiyah Surakarta; 2014.

11. Susanta IPA, Sudiana IK, Sudarmada IN, Or S. Pengaruh Pelatihan Incrimental Vertical Hop Terhadap Kelincahan Dan Kekuatan Otot Tungkai Pada Siswa Putra Kelas X Sma N 1 Selat Tahun Pelajaran 2014/2015. Jurnal Ilmu Keolahragaan Undiksha. 2014;2(1).

12. Adiatmika I, IGPNA S. Tes dan Pengukuran Olahraga. Denpasar, Bali, Indonesia: Udayana University Press; 2016.

13. Valentina N, Kurniawati PM, Maramis MM. Correlation of Lower Limb Muscles and Body Mass Index with Body Balance in the Elderly. Folia Medica Indonesiana. 2019;55(1):58-62.

14. Nurmalasari M, Widajanti N, Dharmanta RS. Hubungan Riwayat Jatuh dan Timed Up and Go Test pada Pasien Geriatri. Jurnal Penyakit Dalam Indonesia. 2018;5(4):1648 . 
15. Utomo B, Takarini N. Uji validitas kriteria Time up and go test (TUG) sebagai alat ukur keseimbangan pada lansia. Jurnal fisioterapi. 2009;9(2):86-93.

16. Estes E. Timed Up and Go (TUG) Test and Its Effectiveness in Fall Risk Screening and Assessing the Success of the Stepping on Program in Fall Prevention. 2016.

17. Sapti A. Perkembangan Usia Mempengaruhi Kekuatan Otot Punggung pada Orang Dewasa Usia 40-60 Tahun. Gaster. 2018;16(1):1-5.

18. Deniro AJN, Sulistiawati NN, Widajanti N. Hubungan antara Usia dan Aktivitas Sehari-Hari dengan Risiko Jatuh Pasien Instalasi Rawat Jalan Geriatri. Jurnal Penyakit Dalam Indonesia. 2017;4(4):199-203.

19. Hastuti H. The Effect Of Freeletic Exercise On Leg Strength In The Freeletic Community Of Makassar. Nusantara Medical Science Journal. 2018:27-31.

20. Nasution KN. Kadar Testosteron dengan Infark Miokard Akut pada Orang-Orang Indonesia. 2019.

21. Susilo W, Limyati Y, Gunawan D. The Risk of Falling in Elderly Increased with Age Growth and Unaffected by Gender. Journal of Medicine and Health. 2017;1(6)

22. Sihombing F, Athuhema TK. Hubungan Antara Usia Dan Jenis Kelamin Lansia Dengan Risiko Jatuhdi Pstw Unit Abiyoso Yogyakarta.

23. Salsalbira S, OR WSFM. Hubungan antara Perubahan Postur Tubuh terhadap Keseimbangan Dinamis pada
Lansia: Universitas Muhammadiyah Surakarta; 2019.

24. Rahayu PAS, Adhitya IPGS, Wiryanthini IAD. Hubungan Fleksibilitas Otot Hamstring Terhadap Keseimbangan Dinamis Pada Lansia Di Desa Serai, Kintamani.

25. Nyman SR, Ingram W, Sanders J, Thomas PW, Thomas S, Vassallo M, et al. Randomised controlled trial of the effect of Tai Chi on postural balance of people with dementia. Clin Interv Aging. 2019;14:2017.

26. Kuo F-C, Chang S-T, Liao Y-Y, Lee C-H. Center of pressure trace and sensory components of the limits of stability test in older adults with vertebral compression fractures. J Geriatr Phys Ther. 2020;43(1):24-31.

27. Wungouw HI, Marunduh S. Pengaruh latihan beban terhadap kekuatan otot lansia. eBiomedik. 2015;3(1).

28. Jung H, Yamasaki M. Association of lower extremity range of motion and muscle strength with physical performance of community-dwelling older women. J Physiol Anthropol. 2016;35(1):1-9.

29. Utami BR, Sari YM. Hubungan Antara Kekuatan Otot Tungkai Dengan Risiko Jatuh Pada Lanjut Usia Di Desa Jaten Kecamatan Juwiring Klaten: Universitas Muhammadiyah Surakarta; 2017.

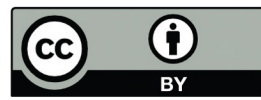

This work is licensed under a Creative Commons Attribution 